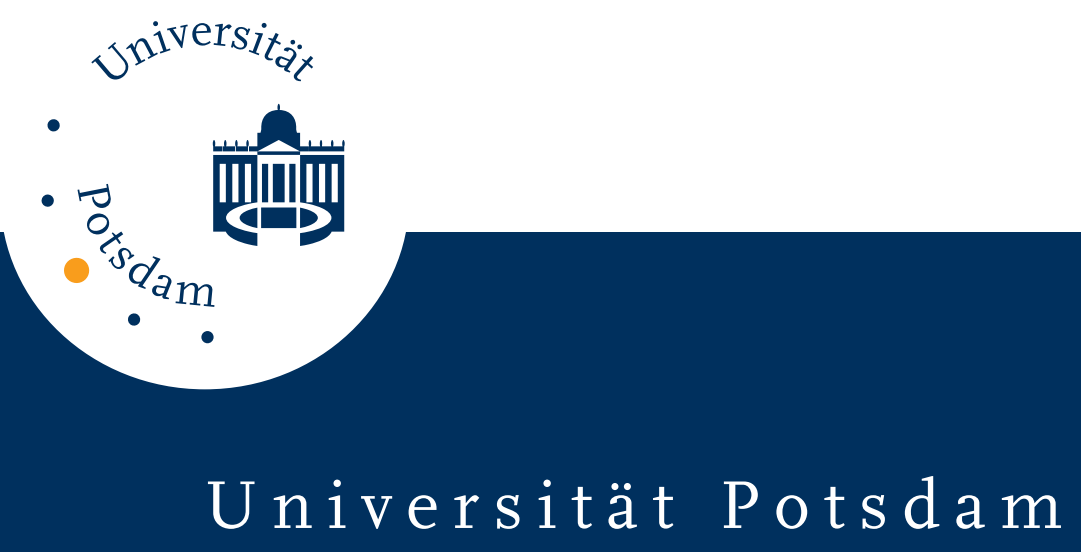

Chryse Hatzichristou, Diether Hopf

\title{
School performance and adjustment of Greek remigrant students in the schools of their home country
}

first published in:

Applied Psycholinguistics 13 (1992) 3, S. 279-294, ISSN 0142-7164, DOI 10.1017/S0142716400005646

Postprint published at the Institutional Repository of Potsdam University:

In: Postprints der Universität Potsdam

Humanwissenschaftliche Reihe ; 98

http://opus.kobv.de/ubp/volltexte/2009/3635/

http://nbn-resolving.de/urn:nbn:de:kobv:517-opus-36352

Postprints der Universität Potsdam

Humanwissenschaftliche Reihe ; 98 


\title{
School performance and adjustment of Greek remigrant students in the schools of their home country
}

\author{
CHRYSE HATZICHRISTOU and DIETHER HOPF \\ Max Planck Institute
}

ADDRESS FOR CORRESPONDENCE
Max Planck Institute for Human Development and Education, Lentzeallee 94, 1000 Berlin 33,
Germany

ABSTRACT

This study explores the adjustment of Greek remigrant students in Greek public schools after their families' return to Greece from the Federal Republic of Germany. Teacher and self-rating instruments were used, and achievement and language competence data were obtained. The sample consisted of 13- to 15-year-old junior high school students in northern Greece. The remigrant students were divided into two groups ("early return" and "late return"), based on the year of return to Greece. The control group consisted of all the local classmates of these students. Remigrant students (mainly late return) were found to experience difficulties mainly in the language/learning domain and less in the interpersonal and intrapersonal behavior domains.

Children of migrant workers in the Federal Republic of Germany (FRG) ${ }^{1}$ are at a disadvantage with regard to school success and the type of secondary school they attend as compared to their German peers. They are underrepresented in grammar schools (Gymnasium: prerequisite for university entrance) and secondary technical schools (Realschule: intermediate) and overrepresented in secondary modern schools (Hauptschule: leading to vocational training or work). Although the children of migrant workers have recently shown considerable improvement in their school success, particularly in some areas of the FRG (Hopf, 1987), the majority of foreign children still score below their German counterparts. Remigration to the home country also constitutes a critical and difficult process for all the members of migrant worker families.

This study explores the school performance and adjustment of Greek remigrant children. Greek migration to and from the FRG has been considerable during the last 30 years. Greece is a small country with about 10 million inhabitants. Of these, $1,034,432$ persons entered Germany between 1960 and 1987. During the same time interval, 912,400 Greeks left Germany. Some of the returned migrants later entered Germany for a second time. Furthermore, many Greek children have been born in the FRG. Taking double migration into consideration, it has been estimated that about 
$80 \%$ of Greek migrants have returned to Greece after having been in Germany for at least 10 years (Hopf, 1988). It has been further estimated that since about the middle of the 1970s, approximately 10,000 Greek children have remigrated to Greece each year (Markou, 1984), a number that was quite visible in the Greek educational system. By far the highest percentage of remigrant families comes from the FRG (Hopf, 1988).

As far as the reasons for migration and remigration are concerned, Kasimatis (1984) stated that most of the relevant studies show that while a decision to migrate is mainly based on economic factors, a remigration decision is mainly a result of social/psychological factors. Unger (1981), in his study of Greek families who remigrated from the FRG to Greece, found the education of the children to be the most frequent reason for family remigration.

It is important to note that Greek parents put a lot of emphasis on the education of their children during their time abroad. Of particular importance is learning the mother tongue as a means of keeping their children rooted in the Greek tradition to facilitate the possible return to their home country. Empirical research findings have shown that the majority of Greek parents in the FRG desire that their children have at least a secondary school diploma, and that they prefer a Greek schooling for their children (Bundesminister für Arbeit und Sozialordnung, 1981; Damanakis, 1978; Gerstenmeier \& Hamburger, 1974; Savvidis, 1975).

Regarding teaching the mother tongue to the children of Greek workers in the FRG, some basic information is required in order to interpret the performance and adjustment of remigrant children in the schools in Greece. About two-thirds of the Greek students in the FRG attend classes in the mother tongue. There are five different types of mother tongue instruction for Greek students in the various states of the FRG that have been relevant for the children under consideration. They differ regarding the number of lessons per week and the curriculum (Greek Ministry of Education, 1986; Kourtalides, 1984; Tsiplitaris, 1982). An average $31 \%$ of all Greek children of school age do not attend any type of mother tongue classes; the older the children, the lower the proportion of the age group attending such courses.

The Greek labor migrants in Germany enjoy special attention from their government: there are, on an ongoing basis, about 1,300 Greek teachers in the FRG (paid by the Greek government and replaced after about 5 years of stay in Germany) who take care of teaching the Greek language, Greek history, and other subjects of the Greek official curriculum. Teaching materials are either exported from Greece to the FRG or newly developed for the needs of the migrant students.

The problem of home language maintenance and competence is a very critical one, especially when it is connected to a family's return to the home country and the subsequent educational and occupational future of the children there. Appel and Muysken (1987) considered various interrelated factors, such as status factors, demographic factors, institutional support 
factors, and cultural (dis-)similarity to affect language maintenance and shift.

In reviewing the relevant literature on the various types of mother tongue teaching of foreign children in different countries, Ekstrand (1983) concluded that, mainly due to a mismatch between language and the sociocultural environment, resulting in a lack of sociocultural support, language competence of migrant children will not remain at or reach a nativelike level when they live abroad. Findings of studies on Finnish students in Sweden have shown that they have lower school achievement and lower performance on tests of Finnish and mathematics as compared to the Finnish control students in Finland.

Research by Cummins (1981) offered a conceptual distinction between academic and social/conversational language skills, which we believe is critical for explaining the nature of the language difficulties of migrant students. He identified two major dimensions of language proficiency: communicative language skills and academic language skills. Cummins regarded all tasks requiring language skills to be conceptualized along two continua. The horizontal continuum concerns the degree of contextual support in a communicative activity having two extremes: the "contextembedded" extreme, where meaning is negotiated between the participants and communication is supported by various contextual cues; the "contextreduced" extreme, where context is reduced and communication is mainly based on linguistic cues. The vertical continuum concerns the degree of cognitive involvement in a communicative activity and has two extremes: cognitively undemanding and cognitively demanding. Based on this scheme, the distinction between basic interpersonal communicative skills (which reflect a superficial linguistic fluency in context-embedded and cognitively less demanding situations) and the cognitive/academic aspects of language proficiency (needed in cognitively and linguistically more demanding decontextualized tasks) becomes essential for determining and evaluating the first language (L1) or second language (L2) proficiency of bilingual children.

Research studies on the language problems, school performance, and adjustment of immigrant children usually focus on the situation of these children in the host country. Our study, however, deals with the return migrants who for many years have already experienced a difficult bilingual situation in the target country of migration and who, after return to their home country, have to handle a new and equally complicated linguistic situation. According to the few existing relevant studies, after remigration to their parents' home country, Greek migrant children encounter various educational, psychological, and sociocultural difficulties. In particular, these students are described as experiencing problems with the Greek language, school homework, curriculum of the different courses, communication with the teachers, peer relationships, and social integration into the school system (Dikaiou, Sakka, Manavopoulos, Brikas, \& Fatourou, 1984; Gotovos, Markou, \& Fehring, 1987; Kiliari, 1986; Unger, 1986). Most of 
these studies, though, exhibit methodological limitations, mainly due to restricted samples and/or the use of the students' perspective only, and do not cover the various aspects of the adjustment process.

The aim of this study was to explore Greek remigrant children's adjustment in Greek public schools using a sample of 784 junior high school students. An effort was made to examine whether the remigrant students encountered difficulties in the academic, social, and personal domains in adapting to the home country (as previous research findings suggested), and if so, to analyze the nature of these difficulties. The variables under consideration are related to the larger context of the students' school environment, such as school achievement, language competence, student selfconcept, and teacher judgments of the students on different dimensions. The adjustment of remigrant children was assessed using the perspectives of teachers and self. It has been argued that using a multiple approach leads to a better understanding of children's exhibited behavioral repertoire and social adjustment than using only one perspective'(Hatzichristou, 1987; Hatzichristou \& Swain, 1988). Besides the data on social and academic adjustment, data on the educational history, school performance, and language competence of the students were obtained.

More specifically, our hypotheses are that Greek remigrant children experience more social adjustment and school adaptation difficulties as compared to local children; that the length of stay in Greece (after remigration) constitutes a critical factor regarding the nature and severity of the difficulties the children face; and that language competence constitutes a critical variable in the remigrant children's adjustment process.

\section{METHOD}

\section{Sample}

The sample consisted of 13- to 15-year-old students who attended $29 \mathrm{sec}$ ond- and third-grade ${ }^{2}$ classes in 11 different public junior high schools (Gymnasia) in northern Greece. Of these students, 139 (16.1\% of the sample) had lived abroad; $133(95.7 \%)$ of these were born abroad and remigrated to Greece at different time periods. The 139 students remigrated to Greece from different countries: FRG $(N=116,13.5 \%$ of the total sample), Australia $(N=7,0.8 \%)$, United States $(N=5,0.6 \%)$, Sweden $(N$ $=4,0.5 \%)$, Africa $(N=3,0.3 \%)$, Eastern Europe $(N=3,0.3 \%)$, and Central/South America $(N=1,0.1 \%)$.

From the students who had remigrated from the FRG, only those who had spent at least 2 years in the German education system were selected for analysis. A median split procedure was carried out to divide these return students into two groups based on the year of their return to Greece:

1. The "early return" group consisted of $\mathbf{3 1}$ students ( 18 males, 13 females) who had returned to Greece between 4 and 9 years before the time of data collection and had spent between 6 and 12 years in the FRG $(M=$ 8.4 years). All but one of the children were born in Germany. 
2. The "late return" group consisted of 32 students ( 15 males, 17 females) who had returned to Greece between 1 and 3 years before the time of data collection and had spent between 10 and 15 years in the FRG $(M=$ 11.9 years). All children were born in Germany with the exception of two.

The control group consisted of 721 students ( 383 males, 338 females), all classmates of the remigrant students in the classes of the sample, and all of whom were born and raised in Greece.

The educational history of remigrant students in the host country is important and critical, since it is expected to affect the success and/or failure of the students in the school system of their home country.

More than $75 \%$ of the migrant children in our sample attended kindergarten during their stay in the FRG. This mirrors an important change in the migrants' behavior since, in the early years of migration, the children of migrant workers attended kindergarten only in rare cases. Over $75 \%$ of those children who had attended kindergarten went to a German (as opposed to a Greek) kindergarten. Some parents sent their children to both Greek and German institutions.

Nearly $90 \%$ of the early return group and all children of the late return group attended primary school in Germany. The majority of the return children (about $78 \%$ in each return group) had attended two primary schools, one Greek and one German. Since German schooling is compulsory for all children of the respective age group (with the exception of only 1 of the 11 states), our data show the strong inclination of the Greek migrants to raise their children in the tradition of the home country. This interpretation does not contradict the previously mentioned tendency of Greek parents to send their children to a German kindergarten. The observations rather reflect an attitude of Greek parents that can also be observed in the home country: that is, high educational aspirations for their children (which seem to be even higher within the group of Greek migrants; Hopf, 1987), even if this strategy greatly increases the children's work load. None of the migrant students attended a special school in the FRG.

Secondary schools were not attended by children belonging to the early return group (since they were too young at the time of return or had repeated a grade in primary school). Of the late return group, nearly $50 \%$ went to the Hauptschule, another third to the Realschule, and few to the Gymnasium or the Gesamtschule. In addition, we found a few children who attended the Greek "Gymnasio" (junior high school) in the FRG. ${ }^{3}$ Roughly speaking, the proportion of students attending the different mother tongue courses corresponds to the overall figures mentioned earlier.

Finally, it should be mentioned that only a minority of the late return children attended special classes arranged for remigrant students in Greece. These special classes had not yet been started when the early return students returned to Greece. From the late return group, about every sixth person attended such a class, that is, the recently established frontistiriaka tmimata. $^{4}$

When comparing the educational history of the migrant students in Ger- 
many with the average education of the control group in Greece, the differences are obvious: local children in Greece go to a 6-year compulsory elementary and a 3-year compulsory junior high school. Kindergarten (private and public) attendance was about $54 \%$ of the age cohort under consideration. $^{5}$

\section{Instruments and procedures}

Teacher rating and self-rating instruments were used. The participation of the teachers and the students was voluntary; however, all teachers and students who were asked agreed to participate. The purpose of the study, with a primary emphasis on the social adjustment indices of the children of this age, was explained to the teachers of the target classes. ${ }^{6}$ In addition, written and verbal instructions for the teacher rating instrument were given to the teachers. Furthermore, a general introduction about the study was made by the researchers for the students of each class, focusing mainly on the students' self-perception. Comments about remigrant students were not made in order to avoid any possible influence on the students' answers.

The teachers were asked to fill out for each student in every class a revised and translated version of the Pupil Behavior Rating Scale (PBRS) (Lambert \& Bower, 1962), which consists of 11 items concerning schoolrelated behavior, assessed on a 5-point scale. Example items are: "This student has difficulty in following teachers' directions," or "This student is usually shy and isolated."

The teachers were also asked to evaluate the performance (4-point scale) and the competence (5-point scale) of each remigrant student in the four major aspects of language: speaking, writing, listening, and reading (Macnamara, 1967). Achievement data (scores of 1-20: $10=$ passing grade, 20 $=$ excellent) on language, mathematics, and history courses at the end of the academic year were also obtained from the students' files.

The students were asked to fill out a translated version of the SelfDescription Questionnaire (SDQ) II (Marsh \& Barnes, 1982; Marsh, Parker, \& Barnes, 1985), consisting of 102 items (5-point scale) after the omission of the corresponding items of the "honesty" scale due to its irrelevance for the Greek educational setting.

SDQ is a measure of self-concept derived from the Shavelson multifaceted, hierarchical model of self-concept (Shavelson, Hubner, \& Stanton, 1976). Example items ${ }^{8}$ are "I often have to read things several times before I understand them," "I have trouble expressing myself when trying to write something," "Overall, I have a lot of self-confidence," "I make friends easily with members of the opposite sex," and "Overall, I do lots of things that are important" (5-point scale). Research findings of the SDQ support the multidimensionality of self-concept (Marsh, Parker, \& Barnes, 1985; Marsh, Smith, \& Barnes, 1983; Marsh, Smith, Barnes, \& Butler, 1983).

Finally, the remigrant students were asked to fill out a questionnaire regarding their length of stay in the FRG and Greece, the type of German 
schools attended, their grades in German schools, whether they had attended a Greek school in the FRG, and their grades in Greek schools in the FRG.

\section{RESULTS}

Since the instruments had never been used in Greece before and had been translated into Greek for the purpose of this study, they were first analyzed for their psychometric features in the whole sample, and the distributions of single items and combined scores were considered. The data of the whole sample then was factor-analyzed (using the classical factor solution method followed by varimax rotation) in order to find out about the structure of the instruments and determine indices and scales to be used for group comparisons. Reliabilities were computed using Cronbach's alpha coefficient.

Missing cases were excluded either listwise or pairwise for the purpose of determining the structure of the instruments by factor analysis. When comparing the three groups of students (local, early return, and late return), cases with missing data were replaced by the group means. ${ }^{9}$ Differences between the groups were examined according to our hypotheses using planned contrasts.

\section{Factor analyses and reliabilities of the instruments}

A factor analysis of the 11 variables of the teacher rating instrument ${ }^{10}$ yielded three factors that are similar to the factors found in American research (Table 1).

Factor 1, Classroom Adaptation (explaining $51 \%$ of the variance), included these items with highest loadings: Student has difficulty in learning; has difficulty in following directions; does not like school; is easily distracted. Factor 2, Interpersonal Behavior (explaining $14.7 \%$ of the variance), included the following items: Student shows dangerous behavior; is not obedient; quarrels often; shows immature/inappropriate responses; is sick or stays home when having problems. Factor 3, Intrapersonal Behavior (explaining $9.7 \%$ of the variance), included these items: Student is isolated; is unhappy/depressed. The reliabilities (Cronbach's alpha) of the scales consisting of the items of the factors with loadings above .30 were $.92, .86$, and .77 , respectively.

The self-rating instrument was factor-analyzed also using the classical factor solution method followed by varimax rotation. ${ }^{11}$ Ten factors were extracted, which explained $42.9 \%$ of the variance (Table 2). The reliabilities (Cronbach's alpha) of the scales consisting of the items of the factors with loadings above .30 were between .91 and .67 .

\section{Teacher rating}

Analysis of variance revealed a significant group effect for the classroom adaptation factor of the teacher rating (items: difficulty in learning; difficulty in following directions; does not like school; easily distracted; 
Table 1. Factors of the teacher rating instrument

\begin{tabular}{|c|c|c|c|c|}
\hline Items & & Factor $1^{a}$ & Factor $2^{b}$ & Factor $3^{c}$ \\
\hline 1. & $\begin{array}{l}\text { This student quarrels with } \\
\text { other students more often } \\
\text { than others }\end{array}$ & .253 & .754 & -.081 \\
\hline 2. & $\begin{array}{l}\text { This student has difficulty in } \\
\text { following teacher's direc- } \\
\text { tions }\end{array}$ & .865 & .199 & .128 \\
\hline 3. & $\begin{array}{l}\text { This student does not behave } \\
\text { in a proper way at school } \\
\text { (immature or not appro- } \\
\text { priate behavior for the stu- } \\
\text { dent's age and situation) }\end{array}$ & .436 & .719 & .187 \\
\hline 4. & $\begin{array}{l}\text { This student is usually shy and } \\
\text { isolated }\end{array}$ & .175 & -.053 & .858 \\
\hline 5. & $\begin{array}{l}\text { This student is easily dis- } \\
\text { tracted }\end{array}$ & .724 & .413 & .272 \\
\hline 6. & $\begin{array}{l}\text { This student behaves in ways } \\
\text { which are dangerous to self } \\
\text { and others }\end{array}$ & .152 & .844 & .063 \\
\hline 7. & $\begin{array}{l}\text { This student does not like } \\
\text { school and has no enthusi- } \\
\text { asm to learn }\end{array}$ & .838 & .288 & .204 \\
\hline 8. & $\begin{array}{l}\text { This student has difficulty in } \\
\text { learning }\end{array}$ & .870 & .187 & .245 \\
\hline 9. & $\begin{array}{l}\text { This student becomes sick or } \\
\text { upset or may stay home } \\
\text { from school when faced } \\
\text { with a difficult problem or } \\
\text { situation }\end{array}$ & .211 & .591 & .462 \\
\hline 10. & $\begin{array}{l}\text { This student seems unhappy } \\
\text { and depressed }\end{array}$ & .278 & .177 & .838 \\
\hline 11. & $\begin{array}{l}\text { This student is not obedient } \\
\text { and questions the teacher's } \\
\text { authority }\end{array}$ & .180 & .818 & .094 \\
\hline
\end{tabular}

${ }^{a}$ Classroom Adaptation.

${ }^{b}$ Interpersonal Behavior.

'Intrapersonal Behavior.

$F(2,781)=3.102, p<.04)$. As expected, planned contrasts between the groups showed that late return students $(M=-.40)$ have significantly more classroom adaptation difficulties than control students $(M=.02)$ as seen by the teachers $(t=-2.34, p<.019)$. Regarding the other two fac- 
Table 2. Factors of the self-rating instrument

\begin{tabular}{|c|c|c|c|}
\hline & $\begin{array}{l}\text { Var. } \\
\text { expl. }\end{array}$ & alpha & Title of Factor \\
\hline Factor 1 & 13.9 & .85 & $\begin{array}{l}\text { Verbal competence - General school achieve- } \\
\text { ment. } 22 \text { items. Example: I learn quickly in } \\
\text { most academic subjects }\end{array}$ \\
\hline Factor 2 & 6.8 & .91 & $\begin{array}{l}\text { Physical abilities. } 10 \text { items. Example: I like to } \\
\text { exercise vigorously at sports and/or physical } \\
\text { activities }\end{array}$ \\
\hline Factor 3 & 4.5 & .86 & $\begin{array}{l}\text { Positive physical appearance; positive self- } \\
\text { concept. } 16 \text { items. Example: I am good look- } \\
\text { ing; Overall, I have pretty positive feelings } \\
\text { about myself }\end{array}$ \\
\hline Factor 4 & 3.3 & .89 & $\begin{array}{l}\text { Mathematics. } 10 \text { items. Example: I have trouble } \\
\text { understanding anything that is based upon } \\
\text { mathematics }\end{array}$ \\
\hline Factor 5 & 3.2 & .82 & $\begin{array}{l}\text { Relations with opposite-sex peers. } 11 \text { items. Ex- } \\
\text { ample: I make friends easily with members of } \\
\text { the opposite sex }\end{array}$ \\
\hline Factor 6 & 2.8 & .75 & $\begin{array}{l}\text { Relations with parents. } 9 \text { items. Example: I } \\
\text { would like to bring up children of my own like } \\
\text { my parents raised me }\end{array}$ \\
\hline Factor 7 & 2.6 & .77 & $\begin{array}{l}\text { Emotional stability. } 9 \text { items. Example: I tend to } \\
\text { be a very nervous person }\end{array}$ \\
\hline Factor 8 & 2.3 & .73 & $\begin{array}{l}\text { General self. } 8 \text { items. Example: Overall, I am not } \\
\text { very accepting of myself }\end{array}$ \\
\hline Factor 9 & 1.9 & .77 & $\begin{array}{l}\text { General school/academic motivation. } 7 \text { items. } \\
\text { Example: I am an avid reader }\end{array}$ \\
\hline Factor 10 & 1.7 & .67 & $\begin{array}{l}\text { Relations with same-sex peers. } 10 \text { items. Exam- } \\
\text { ple: I make friends easily with members of the } \\
\text { same sex }\end{array}$ \\
\hline
\end{tabular}

tors of the teacher rating instrument, the groups did not differ from each other.

\section{Achievement and language competence}

There were no significant differences of return students' ability in language - including ability in oral language, understanding the lesson, written language, and reading - as assessed by the teachers (4-point scale). Significant group effects were found for the grades of all school subjects about which we collected data. These were as follows: language: $F(2,781)$ $=9.66, p<.000$; history: $F(2,781)=14.89, p<.000$; math: $F(2,781)$ $=6.20, p<.002$. Significant group effects were also found for the general teacher evaluation of students' performance, $F(2,781)=3.35, p<.035$. 
Table 3. Group comparisons of the achievement variables

\begin{tabular}{lcccccc}
\hline & \multicolumn{3}{c}{ Groups $(M, S D)$} & & \multicolumn{2}{c}{$\begin{array}{c}\text { Group comparisons } \\
(t \text { values })\end{array}$} \\
\cline { 2 - 3 } & Control & $\begin{array}{c}\text { Early } \\
\text { return }\end{array}$ & Late return & $\begin{array}{c}\text { Control } \\
\text { vs. late } \\
\text { return }\end{array}$ & $\begin{array}{c}\text { Early } \\
\text { vs. late } \\
\text { return }\end{array}$ \\
\hline $\begin{array}{c}\text { Evaluation of } \\
\begin{array}{c}\text { students' performance } \\
\text { (4-point scale; (1) } \\
\text { poor, (4) excellent) }\end{array}\end{array}$ & $2.54(1.0)$ & $2.38(1.1)$ & $2.08(.80)$ & $-3.16^{* *}$ & 1.28 \\
$\begin{array}{c}\text { Achievement in } \\
\text { language (1-20) }\end{array}$ & $14.05(3.0)$ & $13.58(2.7)$ & $11.65(2.2)$ & $-5.92^{* *}$ & $3.07^{* * *}$ \\
$\begin{array}{c}\text { Achievement in } \\
\text { history (1-20) }\end{array}$ & $15.26(3.2)$ & $14.20(3.2)$ & $12.19(2.3)$ & $-6.99^{* *}$ & $2.81^{* *}$ \\
$\begin{array}{c}\text { Achievement in mathe- } \\
\text { matics (1-20) }\end{array}$ & $14.12(3.3)$ & $13.52(2.9)$ & $12.09(2.4)$ & $-4.49^{* *}$ & $2.07^{* *}$ \\
\hline \hline
\end{tabular}

${ }^{*} p<.05$.

${ }^{* *} p<.01$.

Planned contrasts of the pairwise differences were performed. They showed that, as expected, late return students had significantly lower achievement than control and early return students (Table 3 ).

The year of return to Greece (for the remigrant groups combined) was further found to be negatively correlated at a statistically significant level to the achievement variables: language $(-.43)$, history $(-.50)$, and math (-.34). Similarly, teachers' evaluation of remigrant students' language performance variables (ability in oral language, in understanding the lesson, and in written language) correlated significantly with year of return to Greece (between -.24 and -.28 ). The later the students returned, the more difficulties they experienced in the schools at home.

The question of whether the different types of schooling during the stay of the return children in the FRG did make a difference in their school performance or adjustment in Greece could not be answered because a large proportion of the answers to the respective items in the questionnaire clearly were not reliable. It seems that these children had enormous difficulties in remembering the specifics of their education (proportion of Greek/German curriculum, grades obtained in German/Greek schools, etc.).

\section{Self-rating}

Analyses of variance revealed significant group effects for the verbal competence/general school achievement factor, $F(2,781)=7.83, p<.0004$, and the positive physical appearance/positive self-concept factor, 
$F(2,781)=2.97, p<.05$. Late return students $(M=.66)$ perceived themselves as having significantly more difficulties in verbal competence and general school achievement than control students $(M=-.03 ; t=$ $3.76, p<.001)$ and early return students $(M=.15 ; t=3.05, p<.003)$. Regarding positive physical appearance/positive self-concept factor, contrary to our expectations, a significant difference $(t=2.03, p<.042)$ in favor of late return students $(M=.35)$ as compared to control students $(M=-.01)$ was found. Regarding the other factors of the self-rating instrument, the groups did not differ.

It is worth mentioning that Factor 1 (Verbal competence - General school achievement) combines items concerning school success (or failure) in most academic subjects with statements concerning verbal competence, such as doing well in tests that require a high verbal reasoning ability or having a good reading comprehension. The combination of these items in a single factor points to the strong verbal loading of the Greek secondary school system, where school success (or failure) is very much dependent on verbal skills. ${ }^{12}$ Children with handicaps in these areas run a high risk of failing in most school subjects.

\section{DISCUSSION}

Based on the teachers' perspective, early return students' behavioral patterns in school did not differ from those of their local classmates'. However, the teachers perceived the late return students as having significantly more difficulties in classroom adaptation and learning than local students. Late return students were also found to have significantly lower achievement in language, history, and math courses as compared to local and early return students.

The students themselves gave an evaluation of their situation which was in good agreement with the assessment given by the teachers. In the selfrating instrument, the late return students reported significantly more difficulties in verbal competence and general school achievement than control and early return students. The late return students' answers to the relevant questions concerning their grades; their learning difficulties and learning speed in most academic subjects; and their ease in learning to read, in reading comprehension, and in expressing themselves in writing, were significantly different from the answers of the control group in the expected direction. This underscores the impression that these students have a realistic picture of their situation in the school; there were no substantial deviations from the teachers' assessment of the situation. The late return students were further found to believe that they are physically more attractive than their local classmates. This finding, whether it reflects reality or not, can possibly be regarded as the children's own defense mechanism, a way of coping with their language and learning difficulties in a school system where verbal competence is strongly related to academic success.

In conclusion, it appears that late return remigrant students experience difficulties in the domains of achievement, learning, and language. These 
difficulties are related to the year of return to Greece: the later the students return, the more difficulties they experience in the schools of their home country. Although the students of our sample are in a different language situation, the observations of Cummins (1981) nevertheless seem to hold: when the evaluation of language proficiency of these children is based on the superficial oral proficiency, the late return children are considered to be competent speakers. However, as soon as more cognitive/academic aspects of language proficiency are required, their deficiencies become apparent. These difficulties are not related to chronological age, since return students and control students are of the same age. On the other hand, and contrary to our hypotheses, remigrant students do not differ from their local classmates in their interpersonal and intrapersonal behavioral patterns as the teachers saw them.

The results in the area of school achievement, and particularly in the language domain, might be considered trivial at first sight. However, upon examining the educational background of the students, and when taking into account the educational policy of the Greek government for citizens living abroad, the findings seem to be of special interest. Particularly in regard to the mother tongue, but also concerning the national school curriculum as a whole, Greece tries very hard indeed to keep the competence level of the students living abroad as close as possible to the national standards and especially to counteract the loss of the mother tongue during migration. Based on the educational history data of the remigrant students in our sample, the majority of them had attended both Greek and German primary schools in the FRG.

On the surface, these investments seem to pay off, at least in the domain of the mother tongue: teachers in Greek schools (in Greece) agreed that students returning from the FRG had a far better language competence in their mother tongue than returnees from other countries (Hopf, 1992). However, the results presented here clearly show that the expectations concerning the effectiveness of the Greek schooling in the FRG were not fulfilled: contrary to the common belief shared by teachers, parents, and administrators, mother tongue teaching in the FRG (in its different forms) neither guarantees Greek language fluency, nor produces acceptable standards in other subjects like history or mathematics. This finding is in agreement with findings of relevant studies mentioned earlier, showing that home language competence and school achievement of students abroad do not reach a nativelike level.

As far as the significantly lower achievement of late return students in mathematics is concerned, the same argument seems to apply. Although one could have expected the return students to reach at least the average Greek standards in mathematics, ${ }^{13}$ according to our casual observations, mathematics teaching and testing in Greek schools is based heavily on verbally loaded procedures. Consequently, the language deficiencies of the returnees also impede their functioning in mathematics.

In contrast, the achievement of early return students who had returned 
to Greece in the lower grades of elementary school has not been found to differ significantly from that of their local classmates. It seems that this is due to the fact that these students have started from context-embedded aspects of language proficiency based on an easier school curriculum and progressed steadily, entering the formal operational stage of cognitive development to context-reduced and cognitively more demanding tasks in school.

It is our prediction that the majority of late return students will not overcome their difficulties completely until they finish school after twelfth grade and, consequently, will have little chance for passing the highly selective entrance examination to the Greek universities (with only about $20 \%$ passing).

On the other hand, the return students do not exhibit any severe interpersonal problems (a fact that indicates a rather smooth social adjustment process), nor do they show remarkable intrapersonal problems as compared to the local students in Greece. Here it is worth noting that Greek migrants in the FRG expose their children to mother tongue teaching and Greek schooling not only for the purpose of academic learning, but also for the development of "Greek identity" in their children. We have no information from our data as to whether the Greek schooling in Germany is successful in meeting this goal; the surprisingly few intrapersonal and interpersonal problems exhibited by the return students when compared to the local students might be interpreted as having been partly effected by the Greek teaching in the country of migration. However, when looking at the social context in which Greeks live while in the FRG, the very well functioning Greek family ${ }^{14}$ and community seem to be especially important factors in the smooth social and personal reintegration of the return students.

\section{ACKNOWLEDGMENTS}

This article is based on an earlier draft that was presented at the Ninth International Association of Applied Linguistics Conference, April 15-21, 1990, Halkidiki, Greece. The authors are grateful to students and staff of the participating schools for their cooperation and participation.

\section{NOTES}

1. We are talking only about the old FRG, consisting of the 11 (old) Länder (states) before the unification with the 5 new Länder of the former German Democratic Republic in October 1990.

2. The Greek school system consists of a 6-year elementary school followed by a 3-year junior high school (Gymnasio) and a 3-year high school (Lykio).

3. It should be added that some answers were missing or were not precise enough to be taken into account. It is our observation that the Greek children have only a vague memory of the frame factors under which they have spent most of their school lives.

4. See Gotovos et al. (1987) and Hopf (1992). 
5. Computed from the Statistical Yearbook of Greece 1986, p. 31, and Education Statistics of Greece 1981/1982, p. 25.

6. The teachers were average teachers of the Greek public education system $(68 \%$ were females).

7. The full scale is presented in Table 1 .

8. For more examples, see Table 2.

9. According to our hypotheses and on the basis of previous research (e.g., Cox, 1983; Forschungsgruppe ALFA, 1984; Hisli, 1987), we expected differences between the students to emerge in connection with their length of stay in Greece (year of return being the key variable); there was no hypothesis that the missing data could be caused by the fact that a subject was a member of one of the groups. For the statistical arguments concerning replacement of missing data see, for example, Rovine and Delaney $(1990$, p. $54 f)$.

10. All students of the sample were included in the analysis. The maximum of missing data for a single item was $9.3 \%$ of the cases. Missing data was deleted pairwise in the factor analysis.

11. Again, all students of the sample were included in the analysis. The maximum of missings for a single item was $6.9 \%$ of the cases. Missing data were deleted pairwise in the factor analysis.

12. This has been pointed out already in literature on Greek education, although not on the basis of empirical data.

13. Mathematics teaching in German schools is of good quality, and the overlap of the German and the Greek mathematics curriculum is larger than the overlap in other subjects (Hopf, 1984).

14. See, for example, Steinhausen (1983).

\section{REFERENCES}

Appel, R., \& Muysken, P. (1987). Language contact and bilingualism. London: Edward Arnold.

Bundesminister für Arbeit und Sozialordnung. (1981). Situation der ausländischen Arbeitnehmer und ihrer Familienangehörigen in der Bundesrepublik Deutschland. Repräsentativuntersuchung '80. Forschungsbericht No. 50, Bonn.

Cox, T. (1983). Cumulative deficit in culturally disadvantaged children. British Journal of Educational Psychology, 53(3), 317-326.

Cummins, J. (1981). The role of primary language development in promoting educational success for language minority students. In California State Department of Education (Ed.), Schooling and language of minority students: A theoretical framework. Sacramento, CA.

Damanakis, M. (1978). Sozialisationsprobleme der griechischen Gastarbeiterkinder in den Grund- und Hauptschulen des Bundeslandes Nordrhein-Westfalen. Kastellaun: Henn Verlag.

Dikaiou, M., Sakka, D., Manavopoulos, K., Brikas, E., \& Fatourou, M. (1984). Children of Greek migrants: A psychosocial approach. In A. Gotovos \& G. Markou (Eds.), School integration of remigrant students: Problems and perspectives. Athens: Ministry of Education/UNESCO. (In Greek)

Ekstrand, L. H. (1983). Maintenance or transition - or both? A review of Swedish ideologies and empirical research. In T. Husén \& S. Opper (Eds.), Multicultural and multilingual education in immigrant countries. Proceedings of an International Symposium held at the Wenn-Gren Center, Stockholm, August 2 and 3, 1982 (pp. 141-159). Oxford: Pergamon. 
Forschungsgruppe ALFA [Ausbildung von Lehrern für Ausländerkinder]. (1984). Einreise vor Beginn der Pflichtschulzeit - Eine Integrationsgarantie für ausländische Kinder? Informationsdienst zur Ausländerarbeit, 1, 55-61.

Gerstenmeier, J., \& Hamburger, F. (1974). Bildungswünsche ausländischer Arbeiterkinder: Ergebnisse einer Befragung von Eltern und Kindern. Soziale Welt, 25(3), 278-293.

Gotovos, A., Markou, G., \& Fehring, M. (1987). School reintegration of returning migrant children in Greece: A first approach. Contemporary Education, 34, 39-45; 35, 49-54; 36, 47-55. (In Greek)

Greek Ministry of Education. (1986). Education of Greek children abroad. Athens: Ministry of Education.

Hatzichristou, C. (1987). Classification and differentiation of socially isolated children. Unpublished $\mathrm{PhD}$ dissertation, University of California, Berkeley.

Hatzichristou, C., \& Swain, C. (1988). Patterns of performance and social adjustment of black and white gifted students in grades one and four. Paper presented at the American Educational Research Association Conference, April 5-9, 1988, New Orleans, LA.

Hisli, N., (1987). The academic and psychological problems of the second generation Turkish migrants. Bilkest Universitesi, Ankara.

Hopf, D. (1984). Unterricht in Klassen mit ausländischen Schülern: Ein Konzept zur Individualisierung und Differenzierung in multiethnisch zusammengesetzten Klassen. Weinheim: Beltz.

(1987). Herkunft und Schulbesuch ausländischer Kinder: Eine Untersuchung am Beispiel griechischer Schüler. Berlin: Max-Planck-Institut für Bildungsforschung.

(1988). Scholia zur griechischen Remigration. Neue Sammlung, 1, 3-15.

(1992). Schulische Wiedereingliederung von Remigrantenkindern in Griechenland: Integrationshilfen durch Förderkurse. Münster/New York: Waxmann.

Kasimatis, K. (1984). Migration - Return migration. Athens: National Center for Social Research. (In Greek)

Kiliari, A. (1986). The linguistic competences of migrant children in German and Greek. A sociolinguistic study. Dissertation, University of Thessaloniki. (In Greek)

Kourtalides, T. (1984). The education of migrant children and the educational policy for Greek children abroad. In A. Gotovos \& E. Markou (Eds.), School reintegration of remigrant students: Problems and perspectives (pp. 20-30). Athens: Ministry of Education UNESCO. (In Greek)

Lambert, N., \& Bower, E. (1962). A process for in-school screening of emotionally handicapped children (pp. 20-30). Princeton, NJ: Educational Testing Service.

Macnamara, J. (1967). The bilingual's linguistic performance - A psychological overview. Journal of Social Issues, 13(2), 58-77.

Markou, G. (1984). Educational policy and research program concerning the school problems of remigrant's children. In A. Gotovos \& G. Markou (Eds.), School reintegration of remigrant students: Problems and perspectives (pp. 63-73). Athens: Ministry of Education UNESCO. (In Greek)

Marsh, H. W., \& Barnes, J. (1982). Self Description Questionnaire II. Sydney: University of Sydney.

Marsh, H. W., Parker, J., \& Barnes, J. (1985). Multidimensional adolescent self-concepts: Their relationship to age, sex and academic measures. American Educational Research Journal, 22(3), 422-444.

Marsh, H. W., Smith, I. D., \& Barnes, J. (1983). Multitrait-multimethod analyses of the Self Description Questionnaire: Student-teacher agreement on multidimensional rating of student self-concept. American Educational Research Journal, 20(3), 333-357.

Marsh, H. W., Smith, I. D., Barnes, J., \& Butler, S. (1983). Self-concept: Reliability, stability, dimensionality, validity and the measurement of change. Journal of Educational Psychology, 75(5), 772-790.

Rovine, M. J., \& Delaney, M. (1990). Missing data estimation in developmental research. In Alexander von Eye (Ed.), Statistical methods in longitudinal research: Vol. I. Principles and structuring change (pp. 35-80). Boston: Academic.

Savvidis, G. (1975). Zum Problem der Gastarbeiterkinder in der Bundesrepublik Deutschland. Dissertation, University of Munich. 
Shavelson, R. J., Hubner, J. J., \& Stanton, G. C. (1976). Self-concept: Validation of construct interpretations. Review of Educational Research, 46(3), 407-441.

Steinhausen, H.-C. (1983). Migration und psychosoziale Adaption: Untersuchungen in Gastarbeiterfamilien. Berlin.

Tsiplitaris, Athanasios. (1982). Gastarbeiterkinder in der Bundesrepublik Deutschland am Beispiel griechischer Kinder. Dissertation, University of Tübingen.

Unger, K. (1981). Greek emigration to and return from West Germany. Ekistics, 290, 369374.

Unger, L. (1986). Zweite Generation und Rückwanderung: Rückkehr in die Heimat oder in die Fremde? Eine empirische Studie zur Remigration griechischer Jugendlicher. Saarbrücken: Verlag Breitenbach. 